\title{
Functional expression of minor histocompatibility antigens on human peripheral blood dendritic cells and epidermal Langerhans cells
}

\author{
Ellen van Lochema, Maarten van der Keur ${ }^{\mathrm{b}}$, A Mieke \\ Mommaas $^{\mathrm{c}}$, Gijsbert C de Gast ${ }^{\mathrm{d}}$ and Els Goulmy
}

\author{
a Department of Immunohematology and Bloodbank, ${ }^{\mathrm{b}}$ Department of \\ Hematology and 'Department of Dermatology, Leiden University Hospital, \\ ${ }^{\mathrm{d}}$ Department of Hematology, Utrecht University Hospital
}

Received 25 Scptember 1995 accepted for publication 25 October 1995

\begin{abstract}
Abstiact. Adequate piesentation and cell suiface expiession of foreign minot histocompatibility antigens $(\mathrm{mHag})$ to allogeneic $\mathrm{T}$ cells can lead to giall versus host disease (GvHD) after HI A matched bone martow tiansplantation (BMT) Cells of the denditic cell (DC) lineage including epidermal Langethans cells (LC) are the most potent inducets of pumay alloseactive T cell iesponses $m i$ vo and $m$ vitro To explore the possible tolc of peripheral blood DC and of skin derived LC in the induction of allommune responses against mHag we andlysed the functional expiession of mHag on these professional antigen presenting cells (APC) To this end cytotoxic T cell (CTL) clones specific for mHag H Y and HA 1 to HA 4 were used to demonstiate the presence of these antigens on highly puified DC and LC Our tesults demonstiate that like other cells of the hematoporetic lineage DC and LC express all the mHag tested for The functional expression of mHag on these potent APC suggests theil involvement in the induction ol $\mathrm{mHag}$ specific GvH directed T cell responses alter allogenesc BMT
\end{abstract}

\section{Introduction}

Giatt versus host disease (GvHD) is still a major complication of allogeneic bone malıow tiansplantation (BMT) In HLA matched BMT minot histocompatıbılity antıgen (mHag) dis partues between bone marow donor and recipsent can play a role in the development of $\mathrm{T}$ cell mediated GvHD 1 ? The alloresporse to mHag in $v_{l i} O$ is supposed to be initiated by piofessional antigen-presenting cells (APC)

Celk of the denditic cell (DC) linedge are well charac teized piofessiond APC They are highly efficient in the initiation of piumaly in ittro T cell responses such as in allogenerc mixed leucocyte ieactions ${ }^{3}$ Moreover DC pulsed with protein antigen $i n$ itro or virally infected DC ale capable of

Addiess lor correspondence E Goulmy Depatment of Immunohema tology and Bloodbank Leiden Universily Hospital Bldg 1 E3 Q POB 96002300 RC Lerden The Nethel lands piming antigen specific MHC iesticted T cells both in vitio and in vivo ${ }^{4}$ (DC are derived from bone mariow precursors and migrate in an immature form via the blood to the nonlymphoid tissues such as the skin $^{7} 9$ Epidermal Langerhans cells (LC) are the best characterized nonlymphord or inter stitial DC They are refetted to as the petipheral outpost of the immune system, with a special iole in the local cutaneous defence ${ }^{1011}$ Within normal epidermis, LC are the only cells that expiess MHC class II molecules and have the capacity to inıliate antigen specific $\mathrm{T}$ cell responses ${ }^{1017}$ Like lymphoid DC, LC die efficient APC in the induction of $T$ cell 1esponses ${ }^{1311}$ Following acquisition and piocessing of ant1 gens, the LC miglate as veled cells through the atferent lym phatics into the draining lymph nodes where they become speclalized at clustering and activatıng nave T cells ${ }^{12} 15 \mathrm{Ic} \mathrm{A}$ iole for $\mathrm{LC}$ in the induction of GvHD has been postulated as the skin is one of the man target organs in GvHD Host LC can persist for a long time after BMT before the epidermis is

(C) Arnold 1996 
repopulated by $\mathrm{LC}$ from donor origin ${ }^{81718}$ Furthermore, LC are the criticd stimulator cells in the in vitro allogeneic epider mal cell-lymphocyte reaction, which may be regarded as an in vitro correlate of the $\mathrm{GvH}$ reaction (1) 20

\section{Objective}

The objective of the present study was to investigate the poss ible role of peripheral blood DC (as possible precursors of LC) and $\mathrm{LC}$ as potent inducers of the $\mathrm{mHag}$ specific GvH directed $\mathrm{T}$ cell responses, by evaluating the functional expression of mHag on these APC mHag generally fall to be recognized by antibodies We therefore used well-characterized mHag spec ific CTL clones as effector cells and assayed them agaunst highly purified DC and LC as target cells in a cytotoxicity assay

\section{Material and methods}

\section{mHag and MHC class I specific cytotoxic T cell clones}

Cytotoxic T cell (CTL) clones specific for the mHag H Y and HA-1, HA 2, HA-3 and HA 4 were characterized previously and are described in detail elsewhere ${ }^{121}$ The CTL clones definme mHag $\mathrm{H} \mathrm{Y}, \mathrm{HA} 1, \mathrm{HA}-2$ and HA 4 are HLA-A2 restricted, whereas mHag $\mathrm{HA} 3$ is recognized in the context of HLA A1 Therefore, MHC class I reactive CTL clones specific for the restriction molecules HLA A2 and HLA A1 were used as control effector cells in the cytotoxicity dssays The characteristics of the mHag and MHC class I specific CTL clones are summarized in Table 1 The CTL clones were thawed and cultured for 2 days on rIL 2 (recombinant interleu kin 2, $20 \mathrm{U} / \mathrm{ml}$ ) betore being used ds effector cells in a ${ }^{51} \mathrm{Cr}$ release assay

\section{Isolation of peripheral blood DC}

Buffy codts derived from 051 of blood from six healthy HLA and $\mathrm{mH}$ antigen typed blood donors were used as source for peripheral blood mononuclear cells (PBMC) Enrichment for peripheral blood DC from PBMC was performed accoiding to the method described by Freudenthal and Steinman ${ }^{22}$ As a final step in the dendritic cell enrichment procedure, cells were sorted on a flow cytometer (FACStar, Becton Dickinson) Cells in the metrizamide low-density fraction were labeled with a mix of phycoerythrm (PE) conjugated mAb (monoclonal antibody) specific for CD3, CD14, CD16, CD20 and CD56 and fluorescein (FITC) conjugated mAb specific for HLA DR (all fiom Becton Dickınson, Belgıum) Cells negative for the lineage specific markers and highly positive for HLA-DR were sorted (Figure 1a) The sorted cell fraction was analysed for ultrastructure by election microscopy, and reandlysed on a FACScan (Becton Dickinson) to confirm its purity Expression of high levels of HLA DP and HLA DQ in addition to the absence of lineage specific markers (other than used for sorting, 1 e CD2, CD33, CD57 and CD19) was used to stain the sorted DC

\section{Isolation of Langerhans cells from epidermal cell suspensions}

Epıdermal cell suspensıons were oblaned from skin of five female patients undergoing reconstructive plastic surgery of the breast or abdomen and were prepared as described by Stingl et $a^{23}$ The patients could not be prospectively typed for HLA and $\mathrm{mH}$ antigens The epidermal cell suspensions were stained for CD1a (OKT6 from Ortho Didgnostics) and processed on a FACStar Cells which were highly positive for CD1a were sorted (Figuie 1b) The sorted cell traction was reanalysed on a FACScan and for ultrastructure by electron microscopy Ultrathın cryosections were incubated with antı HLA class II mAb (PdV5 2) conjugated to $10 \mathrm{~nm}$ collordal gold particles ${ }^{24}$

Table 1 Chatiacteristucs of mHag and MHC class I specific CTL clones used

\begin{tabular}{|c|c|c|c|c|}
\hline \multirow{2}{*}{$\begin{array}{l}\text { CTL rlone } \\
\text { designation }\end{array}$} & \multirow{2}{*}{$\begin{array}{l}\text { HLA }^{b} \\
\text { restriction/specificity }\end{array}$} & \multicolumn{2}{|c|}{$\mathrm{mH}$ antıgen } & \multirow{2}{*}{ Tissued distribution } \\
\hline & & Code & $\begin{array}{l}\text { Phenolype } \\
\text { frequency }(\%)\end{array}$ & \\
\hline cl 2 & $\mathrm{Al}$ & & & \\
\hline $3 \mathrm{E} 2$ & $\mathrm{~A} 2$ & & & \\
\hline $3 \mathrm{HA} 15$ & A2 & $\mathrm{HA} I$ & 69 & Hematoporetıc \\
\hline $5 \mathrm{H} 13$ & A2 & HA 2 & 94 & Hematopoletıc \\
\hline $5 \mathrm{HOl} 1$ & $\mathrm{Al}$ & HA 3 & 88 & Ubiquitous \\
\hline $5 \mathrm{G} 30$ & $\mathrm{~A} 2$ & HA 4 & 16 & Ubiquitous \\
\hline $1 R 35$ & $\mathrm{~A} 2$ & $\mathrm{H} \mathrm{Y}$ & Male & Ubiquitous \\
\hline
\end{tabular}

From Goulmy' and Van Lls $c t a l^{21}$

1 The CTL clones used in this study recognire $m$ Hag in association with cither HLA A.l (5HO11) or HLA A2 (3HAI5 5H13 5G30 and IR35)

Phenotype Irequencies of the mHag in the HLA A1 (HA 3) or HLA A2 (HA 1 HA 2 HA 4 H

Y) positive healthy population

${ }^{1}$ From De Bueger of $a{ }^{30}$ cell types deıtved from several tissues were analysed for then $\mathrm{mHag}$ expression The ussue distribution of HA I and HA 2 was restricted to cells of the hematopoietic linedge (PHA blasts EBV LCL punfied $T$ cells $B$ cells monocytes and immature thymocytes), while mHag HA 3 HA 4 and $\mathrm{HY}$ were detected on all ussues tested hematoporenc and nonhematopotetic cclls (cultured fibroblasts ketatnocytes melanocyles cultured epitheltal cells of kıdney proximal tubulı and umbilical cold vein derived endothelıal cells) 
(a)

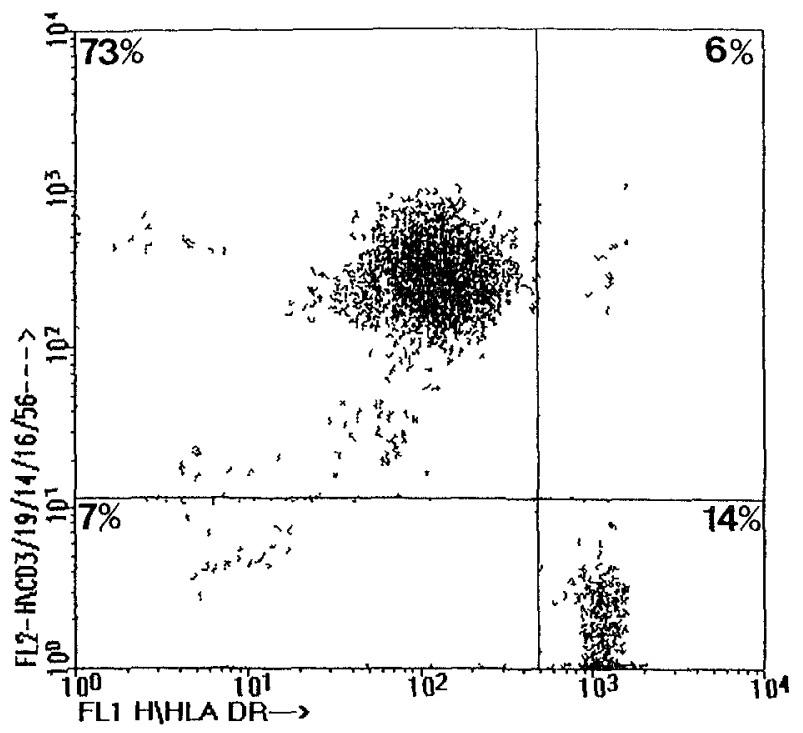

(b)

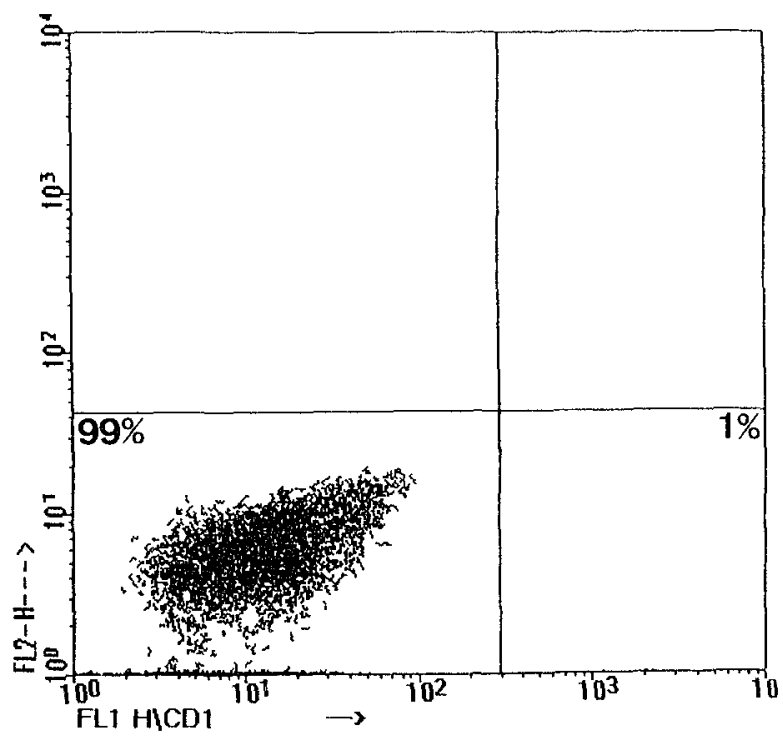

Figure 1 Sorting pardneters for the isolation of peipheial blood DC and epidermal LC (a) Expiession of high levels of HLA DR (FL I) In additıon to the absence of lineage spectic markers (FL 2) were used as sortıng palameters (lower 11ght quadiant) to purıty the enriched DC fractions (b) Langethans cells were sorted from epıdermal cell suspensions $12 \%$ of the single cell suspensions staned for the LC specific marker CDla (FL 1)

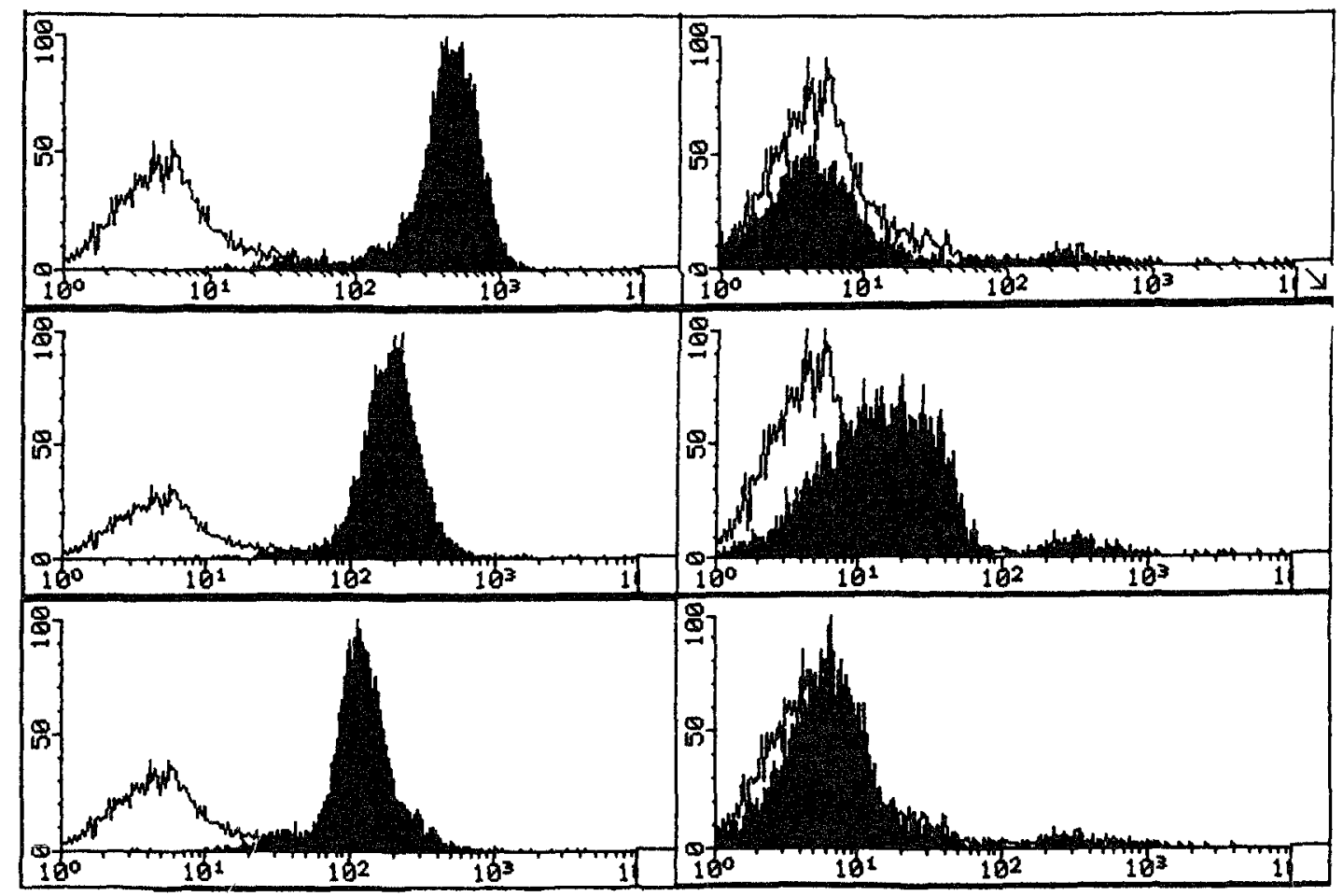

Figure 2 FACS andlysis of the sorted periphesal blood DC Sorted DC were staned with mAb spectuc for HLA DP (B7 21 Becton Dickinson) and HLA DQ (SPvL3 fiom H Spits) for B7 1 and for the lineage specific markers CD2 CD19 and CD33 followed by PE conjugated goat ant1 mouse mAb (background peak)

\section{Cytotoxicity assay}

Expression of the CTL defined mHag on puritied peisheid blood DC and LC was analysed in a standard $4 \mathrm{~h}{ }^{51} \mathrm{C}$ r release assay FACS-sorted DC and LC were used as target cells for the mHag and MHC class I specific CTL clones in effector to taiget ralios of 201 and 21 LC were incubated with IFN- $\gamma$ (intelferon gamma) $200 \mathrm{U} / \mathrm{ml}$ for $48 \mathrm{~h}$ at $37^{\circ} \mathrm{C}$ before being used as target cells Percentages of specific ${ }^{51} \mathrm{Cr}$ release were calculated as follows

$$
\% \text { lysis }=\frac{\text { expetimental telease }- \text { spontaneous release }}{\text { maximal 1elease }- \text { spontaneous teledse }} \times 100
$$


in which the spontaneous ${ }^{51} \mathrm{C}$ release by the different taiget cells is always lower than 20\% FACS sorted DC, pure frac uons of monocytes (>95\% CD14 positive) and phytohemag glutmin (PHA) stımulated $\mathrm{T}$ cell blasts from the same blood donor were tested simultaneously as target cells

\section{Results}

\section{Purity of the FACS-sorted DC and LC}

FACS sorting piovided high puity of both DC and LC FACS analysis of the sorted $D C$ and $L C$ revealed that $>95 \%$ of the cells expressed relatively high amounts of HLA DP and HLA DQ and were positjve for B7 1 andlogous to what was described easlier ${ }^{2225}$ the solted DC were negative for lineage specific markers such as CD2 CD19 and low positive for CD33 (Figure 2) Ultrastructural analysis of the sorted DC (Fugure 3) and LC (Figure 4d) demonstrated that these cells both displayed the specific chadicteristics such as long cyto plasmic processes and a lobulated nucleus the sorted CD1a positive cells clearly displayed Birbeck granules (Figure 4a inset) Immunoelectron microscopy revedled a relatively high expression of class II molecules on the LC, both intracellularly (Figure 4b) and on the cell surface (data not shown) Ultra structural and FACS andysis of the sorted LC futhermore demonstiated that the few keratınocytes conlaminatıng the fractions were not viable

mHag and HLA expression of peripheral blood DC Purtifed preparations of periphetal blood DC from six blood donors were andysed for expression of the $\mathrm{mHag} H \mathrm{H}$ and HA 1 HA 2 HA 3 and HA 4 and of the relevant restriction molecules HLA A2 and HLA A1 DC as well as PHA blasts and monocytes of each individual were assayed simul taneously as target cells with mHag and MHC class I specific CTL The specific lysis percentages of the target cells from three of the six donors ate depicted in Table 2 It is clear that DC were equally suscepuble to lysis by the different CTL clones as the PHA blasts and monocytes of the same donor Thus analogous to PHA blasts and monocytes the mHag

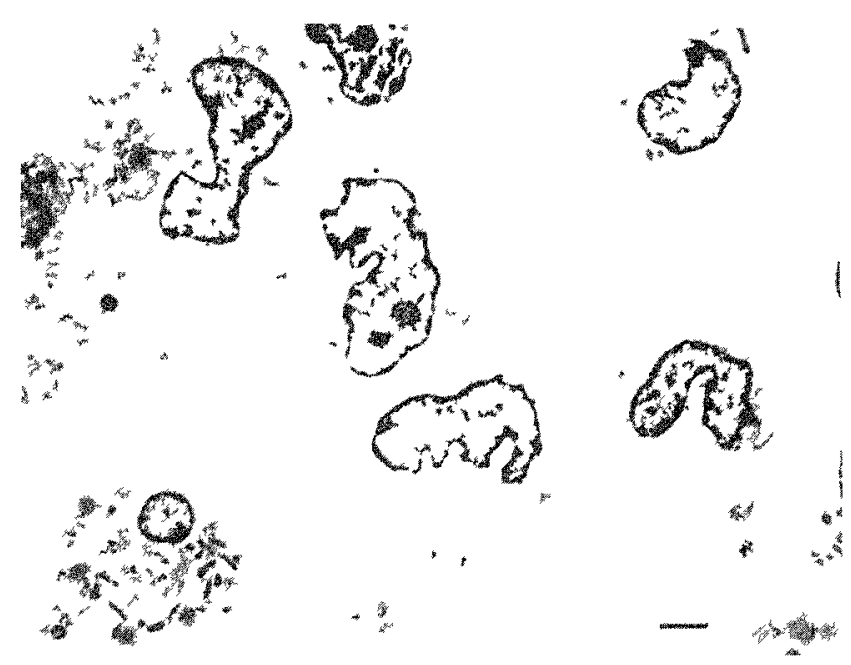

Figure 3 Election micrograph of the sorted CD3 CD14 CD16 CD20 CD56 negative HLA DR posituve cells showing the characturistics morphology of DC such as cyloplasmic processes and a lobulated nucleus $\mathrm{Bar}=2 \mu \mathrm{m}$

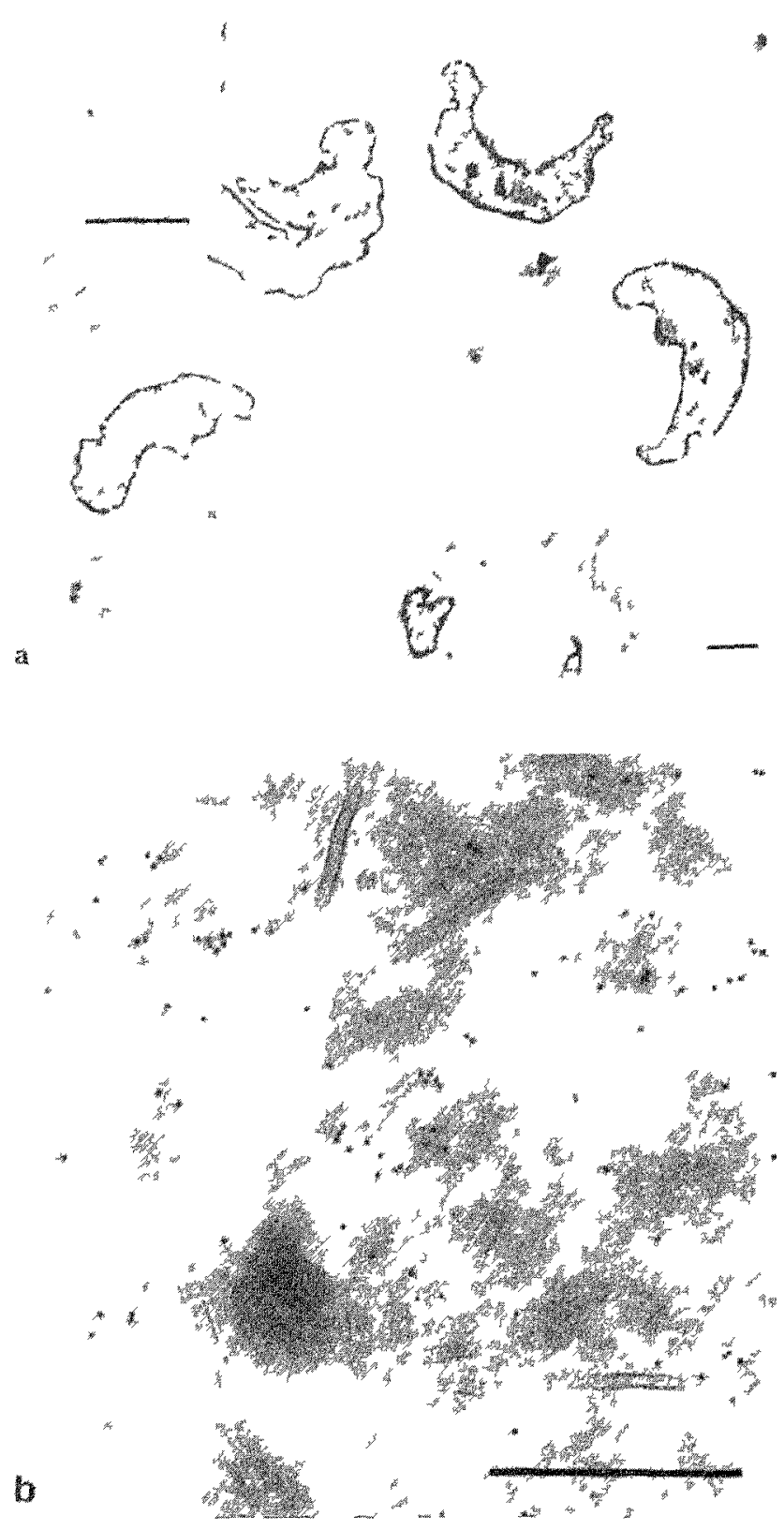

Higure 4 (d) Electuon microglaphs of sorted CDI positive cells showing LC with specific characteristics such as long cytoplasmic processes a lobulated nucleus and Bubeck granules (inset bar = $05 \mu \mathrm{m}$ ) in the cytoplasm of the sor ICd CDI postive cells Bal $-2 \mu \mathrm{m}$ (b) Incubation of ultrathin cryoscctions with ant1 HLA class II mAb (PdV5 2) conjugated to $10 \mathrm{~nm}$ collordal gold particles ${ }^{24}$ 1evealed a relativaly high HLA class II expiession on intiacellula vesicular stuuctures of the sorted LC Bubeck gianules werc negative B ir $05 \mu \mathrm{n}$

HA 1 HA 2 HA 3 HA 4 and H Y are clearly recognized on perspherd blood $\mathrm{DC}$

\section{mHag and HLA expression of epidermal LC}

Pure preparations of LC obtained fiom five temale individuals were analysed for expression of the mHag HA I HA 2 and HA 3 and for their relevant restnction molecules HLA A2 and HI A Al As LC were obtaned solely from female individ uals expression of the male specific mHag $\mathrm{H}$ Y could not be andysed Table 3 shows the specific lysis percentages of the 
Table 2 Lysis of peripheral blood DC by mHag and MHC class I specific CTL

\begin{tabular}{|c|c|c|c|c|c|c|c|c|c|c|}
\hline \multirow[t]{3}{*}{$\mathrm{mH} / \mathrm{MHC}^{\mathrm{b}}$ specincity } & \multirow[b]{3}{*}{$\mathrm{ET}^{\mathrm{d}}$} & \multicolumn{9}{|c|}{ Individuals ${ }^{1}$} \\
\hline & & \multicolumn{3}{|l|}{ D. $A^{c}$} & \multicolumn{3}{|l|}{ D-B } & \multicolumn{3}{|l|}{$\mathrm{D} \sim \mathrm{C}$} \\
\hline & & PHA & Mono & $\mathrm{DC}$ & PHA & Mono & DC & PHA & Mono & $\mathrm{DC}$ \\
\hline \multirow[t]{2}{*}{ HLA Al } & 20 & $83^{c}$ & 48 & 81 & 6 & $\mathrm{nt}$ & $\mathrm{nt}$ & 7 & $\mathrm{nt}$ & 0 \\
\hline & 2 & 75 & 27 & 61 & 3 & nt & $\mathrm{nt}$ & 7 & $\mathrm{nt}$ & 0 \\
\hline \multirow[t]{2}{*}{ HLA A2 } & 20 & 82 & 56 & 83 & 60 & 43 & 77 & 82 & 57 & 61 \\
\hline & 2 & 63 & 30 & 52 & 41 & 15 & 55 & 63 & 20 & 60 \\
\hline \multirow[t]{2}{*}{$\mathrm{HA}-1$} & 20 & 71 & 35 & 68 & 79 & 60 & 104 & 50 & 31 & 52 \\
\hline & 2 & 62 & 11 & 50 & 75 & 51 & 79 & 40 & 25 & 23 \\
\hline \multirow[t]{2}{*}{ HA 2} & 20 & 47 & 30 & 45 & 43 & 34 & 73 & 35 & 36 & 38 \\
\hline & 2 & 28 & 12 & 26 & 38 & 24 & 64 & 26 & 18 & 22 \\
\hline \multirow[t]{2}{*}{ HA-3 } & 20 & 93 & 69 & 85 & 0 & -2 & 1 & 3 & 6 & $\mathrm{nt}$ \\
\hline & 2 & 81 & 38 & 67 & -3 & 0 & 4 & 0 & 0 & $\mathrm{nt}$ \\
\hline \multirow[t]{2}{*}{$\mathrm{HA}-4$} & 20 & 0 & -4 & 0 & 82 & 67 & 93 & 1 & 2 & 2 \\
\hline & 2 & 1 & 5 & 0 & 76 & 45 & 88 & -1 & $\mathrm{nt}$ & $\mathrm{nt}$ \\
\hline \multirow[t]{2}{*}{$\mathrm{H}-\mathrm{Y}$} & 20 & 83 & 44 & 77 & -1 & $\mathrm{nt}$ & nt & 57 & 32 & 41 \\
\hline & 2 & 76 & 31 & 73 & 0 & nt & $\mathrm{nt}$ & 51 & 20 & 40 \\
\hline
\end{tabular}

'PHA stımulated $\mathrm{T}$ cell blasts (PHA), monocytes (mono) and dendritıc cells (DC) are tested simultaneously as target for lysis by $\mathrm{mH}$ specific CTL

${ }^{b}$ Antigen specificity of the clones used (see Table 1 for further information)

${ }^{\circ}$ HLA type of individual D-A (male), A1,2, B7,8, Cw7, DR15,3, DQ1,2, DPw1,w4, individual D-B (female), A2, B27, 40, Cw2,w3, DR11,12, DQ3,

DPw4, individual D-C (male), A2,24, B44,62, Cw3,w5, DR13,4, DQ3,6 DPw3

${ }^{\mathrm{d}}$ Etfector target 1 atio used in the ${ }^{51} \mathrm{Cr}$ release assay

${ }^{6}$ Percentages of specific lysis in a $4-\mathrm{h}{ }^{51} \mathrm{Cr}_{\mathrm{r}}$-release assay

Table 3 Lysis of epidermal Langerhans cells by mHag and MHC class I specific CTL

\begin{tabular}{|c|c|c|c|c|c|c|c|}
\hline \multirow{3}{*}{$\begin{array}{l}\mathrm{mH} / \mathrm{MHC} \\
\text { specificity }\end{array}$} & \multirow[t]{3}{*}{$\mathrm{E} \mathrm{T}^{\mathrm{b}}$} & \multicolumn{6}{|c|}{ Indıvıduals $\mathrm{s}^{\mathrm{a}}$} \\
\hline & & \multicolumn{2}{|c|}{$\mathrm{L}-\mathrm{A}$} & L-B & $\mathrm{L}-\mathrm{C}$ & L-D & L-E \\
\hline & & $-^{\mathrm{d}}$ & + & + & + & + & + \\
\hline \multirow[t]{2}{*}{ HLA-A 1} & 201 & $21^{\mathrm{e}}$ & 71 & 5 & 0 & 3 & 93 \\
\hline & 21 & 18 & $\mathrm{nt}$ & 0 & 0 & 0 & 87 \\
\hline \multirow[t]{2}{*}{ HLA-A2 } & 201 & 2 & 7 & 48 & 51 & 61 & 74 \\
\hline & 21 & 0 & $\mathrm{nt}$ & $\mathrm{nt}$ & 42 & 42 & 67 \\
\hline \multirow[t]{2}{*}{$\mathrm{HA}-1$} & 201 & 3 & 5 & 32 & 57 & 32 & 72 \\
\hline & 21 & 1 & $\mathrm{nt}$ & 23 & 38 & $\mathrm{nt}$ & 59 \\
\hline \multirow[t]{2}{*}{$\mathrm{HA}-2$} & 201 & 0 & 3 & 35 & 32 & 76 & 64 \\
\hline & 21 & 0 & $\mathrm{nt}$ & 31 & 21 & 43 & 43 \\
\hline \multirow{2}{*}{$\mathrm{HA}-3$} & 201 & 19 & 83 & 0 & 2 & 5 & 72 \\
\hline & 21 & 12 & nt & 0 & 0 & 1 & 70 \\
\hline
\end{tabular}

'LC were obtaned from epidermal cell suspensions from skin of five individuals

${ }^{b}$ Effector target ratio used in the ${ }^{51} \mathrm{Cr}$-release assdy

'Antigen specificity of the clones used (see Table I for further information)

"LC were used as tanget for mHag specific lysis after piencubation with (+) IFN- $\gamma$, LC of indrvidual L-A are tested for lysis susceptibility afteı preincubation with $(+)$ and without $(-)$ IFN $\gamma$

'Percentages of specific lysis in a $4 \mathrm{~h}{ }^{51} \mathrm{Cr}$-release assay
LC from the five individuals by the different CTL clones LC of individual L-A were tested as target cells after a 48-h incubation with and without IFN- $\gamma$ The viability of the LC fraction was maintained during this culture step, in which no other cytokınes were added Preliminary FACS analyses of LC of individual L-A, incubated with or withuot IFN- $\gamma$, revealed a significant increase in the expression of ICAM-1, B7-1 and MHC molecules on the surface of the LC after IFN- $\gamma$ incubation (data not shown) Although freshly isolated LC were susceptible to mHag specific lysis by CTL clones (individual L-A $A^{-}$, the lysis susceptibility was markedly enhanced by preincubating the LC for $48 \mathrm{~h}$ with IFN- $\gamma 200 \mathrm{U} / \mathrm{ml}$ (individual L-A ${ }^{+}$) Therefore, LC of individuals L-B, L-C, L-D and L-E were preincubated with IFN- $\gamma$ before being used as target cells The LC are found to functionally express the mHag HA1, HA-2 and HA-3 (Table 3)

\section{Discussion}

The influence of mHag mismatches between bone marrow donor and recipient on the development of GvHD after HLA genotypically identical $\mathrm{BMT}^{1}$ was recently confirmed in a prospective multicentre study Mismatches for mHag HA-1, -2, -4 , or -5 was observed to be significantly associated with the occurrence of $\mathrm{GvHD}^{26}$ The induction of T cell responses to mHag mismatches will depend largely on the type of APC by which the antigens are presented Namely, when the $\mathrm{T}$ cell receptoi/MHC interaction is not aided by appropriate costimulatoly signals, the $\mathrm{T}$ cell can be anergized and will be unresponsive to subsequent tiıggering by professional APC Non- 
professional APC such as keratinocytes and fibroblasts have been found to induce $\mathrm{T}$ cell tolerance to the mHag they express ${ }^{27}$ Therefore, the induction of $\mathrm{mHag}$ specific $\mathrm{T}$ cell Iesponses after BMT is supposed to be controlled by pro fessional APC, expressing high levels of costimulatory molecules Cells of the DC hneage, including interstitial DC such as LC, are described to be the most potent APC in the induc tuon of primary $\mathrm{T}$ cell responses both in vitro and in vivo ${ }^{6} 1011$ The high levels of MHC molecules and the expression of costimulatory molecule $\mathrm{B} 7-1$ on the surface of these professional APC after activation $228 \%$ (Figure 2) contribute to theil superior antigen-presenting capdcity

The expression of mHag on peripheral blood DC and LC, as described in the present study, could indicate a role for cells of the DC lineage in the initiation of mHag specific $T$ cell responses in GVHD Although the recipient is depleted for most hematoporetic derived cells prior to the BMT, residual host leucocytes including cells of the DC lineage are stull present at the moment of BMT In the skin, residual host LC cdn persist for a long time after BMT before the host epidermis is 1epopulated by LC of donor ongin ${ }^{17}$

On the one hand, with theis superior antigen-presenting capacity, these residual host mHag expressing cells of the DC lineage might be involved in the primaly induction of GvH directed mHag specific $\mathrm{T}$ cell responses after BMT Host LC migratıng from the skin through the afterent lymph into the draining lymph nodes, upregulating the expression of MHC and accessory molecules, could stimulate the nave donor derived $T$ cells they encounter ${ }^{24-6}$ Once sensitized by the mHag expressing DC or LC, the activated T cells could readily interact with other mHag positive cells, such as keratinocytes in the skin ${ }^{30}$

On the other hand, the residual host DC and LC may function as target cells for, or restımulate already sensitıced, $\mathrm{mHag}$ specific $T$ cells in GvHD $T$ cells of donor origin may be primed by residual host leucocytes in the circulation, and reactivated by the most potent $\mathrm{APC}$ in the skin, the $\mathrm{LC}$ Decreased numbers of LC in the skin during the course of cutaneous GvHD, as was shown in immunohistochemical studies, suggest a role of LC as target cells ${ }^{1831}$ In that case, the damage to keratinocytes may be a nonspecific effect of lymphokıne release during the lymphocyte/LC interactions Studies on murine LC indicate low or absence of expıession of at ledst some MHC class I on the surtace of LC, making them less susceptible to alloredctive cytotoxic $T$ cell attack ${ }^{32}$ In our piesent study, we found that the low lysis susceptibility of freshly isolated human epidermal LC by MHC class I and mHag specific CTL clones was upregulated after incubation with IFN- $\gamma$ Preliminary FACS analyses revealed that IFN- $\gamma$ may enhance $C T L$ recognition by the upregulation of $M H C$ molecules, B7 1 and ddhesion molecules such as ICAM-1 As there were no other cytokines added to the culture and no viable cytokine-producing cells such as keratinocytes could be detected in the sorted fraction, we ascribe this effect solely to IFN $\gamma$ The in situ release of IFN- $\gamma$ during cutaneous GvHD ${ }^{33}$ may thus effectrvely enhance the recognition of LC by mHag specific CTL clones after BMT, although the data presented in this study cannot directly be extrapolated to an in vivo role of the mHag specific CTL in the GvHD pathogenesis Our study on the functional recognition of mHag on LC and DC links up with previous studies on the tissue distribution of mHag ${ }^{30}$ The results of this study demonstrate that, like other cells of the hematoporetic linedge, DC and LC express all the
mHag we tested for (1 e H Y and HA-1 to HA-4 on the penpheral blood DC, and HA-1, HA 2 and HA-3 on the epidermal LC) The expression of mHag on LC and DC strongly suggests a possible involvement of cells of the DC linedge in $\mathrm{GvH}$ duected mHag specific $\mathrm{T}$ cell responses after allogene1c BMT

\section{Acknowledgements}

The authors would like to thank M Hurks and C Out for making the epidermal cell suspensions, A van der Marel for help with the FACS sorter, A Mulder and I Schadee for making the electron micrographs and F Claas for critıcally reading the manuscript This work was suppoited by grants from the Dutch Cancer Foundation (Koningin Wilhelmina Fonds) and the JA Cohen Institute for 1adiopathology and radiation protection

\section{References}

1 Goulmy $\mathrm{E}$ Minor histocompatibility antigens and theis role in transplantation Transplant Rcv $1988 \quad 2 \quad 29-53$

2 Korngold R, Sprent J Lethal GvHD across minor histocompat vbility barriers nature of the effector cells and role of the $\mathrm{H} 2 \mathrm{com}$ plex Immunol Rev 1983, 71 5-29

3 Steinman RM, Witmer MD Lymphord dendritic cells are potent stimulators of the primary mixed leukocyte reaction in mice Proc Natl Acad Sci USA 1978, 755132

4 Macatonı SE, Taylor PM, Knıght SC, Askonas BA Primary stimulation by dendritic cells induces antiviral proliferative and cytotoxıc T cell responses $/ n$ vitro J Exp Med 1989, 169125564

5 Inaba K Metlay JP Crowley MT, Steinman RM Dendritic cells pulsed with piotein antigens in vitro can prime antigen-specific, MHC restricted T cells in stu / Exp Mcd 1990, $172631-40$

6 Melief CJM Dendritic cells as specidised anugen presentung cells Res Immunol 1989, 140 902-906

7 Kat SI, Tamaki K, Sachs DH Epidermal Langerhans cells are derived flom cells ollginalung in the bone marrow Nature 1979 , $282 \quad 324-26$

8 Pelletier M, Perrault C, Landry D, David M, Montplaisır S Ontogeny of human epidermal Langerhans cells Tiansplantation 1984, 38 544-46

9 Romanı N Schuler G Structural and functional relationships between epidermal Langes hans cells and dendritic cells Res Immu nol 1989 140 895-98

10 Streılein JW, Bergstresser PR Langerhans cells antigen presenting cells of epidermis Immunobiology 1984, 168 285-300

11 Stingl G Tamakı K Kat $\angle$ SI Origin and tunction of epidermal Langerhans cells Immunol Rcv $1980 \quad 53 \quad 149-74$

12 Romani $N$ Schuler $G$ The immunologic properties of epidermal Langerhans' cells as a part of the dendritic cell system Immunopa thology 1992, 13 265-79

13 Braathen LR, Thorsby E Human epidermal Langerhans cells are more potent than blood monocytes in inducing some antigen-spec ific $\Gamma$ cell responses $\mathrm{Br} J$ Dcrmatol 1983, $108 \quad 139-46$

14 Moulon C, Peguet Navarro J, Courtellemont P Redzinak G Schmitt $\mathrm{D}$ In vitro primary sensitization and restimulation of hapten- $\varsigma$ pecific T cells by fresh and cultured human epidei mal Langerhans' cells Immunology 1993, 80 373-79

15 Hoefsmıt ECM, Duıvesiın AM, Kamperdık WA Relation between Langerhans cells, veiled cells, and interdigitating cells Immunobiology 1982, 161 255-65

16 Krıpke ML, Munn CG, Jeevan A Tang J Bucana C Evidence that cutancous antigen presenting cells migrate to regional lymph nodes during contact sensiti/ation J Immunol 1990, 145 2833-37

17 Perrault C Pclletier M Belange1 R et al Persistence of host Lang erhans cells following allogencic bone marrow transplantation possible reldionship with acute grafl-versus host disease $\mathrm{Br} /$ Haematol 1984, 60 253-60 
18 Bieatnach SM, Katz SI Immunopathology of cutaneous gratt-ver sus-host disease Am J Dermatopathol 1987, 9 343-48

19 Faure M, Ftappas A, Schmtt D, Dezutter-Dambuyant C, Thivolet $\mathrm{J}$ Role of HLA DR beaing Langerhans and epidermal indeterm1 nate cells in the in vitro generation of alloreactive cytotoxic $\mathrm{T}$ cells in man Cell Immunol 1984, 83 271-79

20 Bagot M, Mary JY, Heslan M et al The mixed epidermal cell lymphocyte reaction is the most predictive factor of acute graft versus host disease in bone marrow giaft recipients $\mathrm{Br} J$ Haematol $1988,70 \quad 403-409$

21 Van Els CACM, D'Amaro J, Pool $\mathbf{J}$ et al Immunogenetics of human minor histocompatıbility antıgens their polymorphism and immunodominance Immunogenetics 1992, 35 161-65

22 Freudenthal PS, Steinman RM The distinct surface of human blood dendritic cells, as observed after an improved isolation method Proc Natl Acad Sct USA 1990, 87 7698-702

23 Stungl G, Gdzze-Stingle LA, Abeier W, Wolfr K Antigen presentation by murine epideimal Langerhans cells and its alteration by ultiaviolet B light $J$ Immunol 1981, 127 1707-13

24 Mommaas AM, Wijsman MC, Mulde1 AA, van Praag MCG, Vermeer BT, Konıng F HLA class II expression on human epidermal Langerhans cells in situ upregulation during allergic contact det matitis Hum Immunol 1992, 34 99-106

25 Egner W, McKenzie JL, Smith SM, Beard MEJ, Hart DNJ Ident1fication of potent mixed leukocytc reaction-stimulatory cells in human bone marrow, putative differentiation stage of human blood dendutic cells $J$ Immunol 1993, 150 3043-53
26 Goulmy E et al $N$ Engl J Med (in press)

27 De Bueger M, Bakkeı A, Goulmy E Acquired tolerance for minor histocompatıbility antıgens after HLA identical bone marrow transplantation Int Immunol 1992, 4 53-57

28 Young JW, Koulova L, Soergel SA, Clark EA, Sternman RM, Dupont B The B7/BB1 antigen provides one of several costımulatory signals for the activation of $\mathrm{CD} 4^{+} \mathrm{T}$ lymphocytes by human blood dendritic cells in vitro $J$ Clin Invest 1992, 90 229-37

29 Symington FW, Biady W, Linsley PS Expression and function of B7 on human epidermal Langerhans cells $J$ Immunol 1993, 150 1286-95

30 De Buegeı M, Bakker A, van Rood JJ, van der Woude F, Goulmy $\mathrm{E}$ Tissue distribution of human minor histocompatibility antigens Ubiquitous veisus restı1cted tissue distribution indicates heterogenelty among human CTL defined non-MHC antigens $J$ Immunol 1992, 149 1788-94

31 Breatnach SM, Shımada S, Kovac Z, Katz S Immunologic aspects of acute cutaneous graft-versus-host disease decreased density and antigen-presenting function of $\mathrm{Ia}^{+}$Langerhans cells and absent antIgen-presentmg capacity of la' keratinocytes $J$ Invest Dermatol 1986, 86 226-34

32 Sharrow SO, Barden LA, Singe1 A, Katz SI Quantitative differ ences in cell surface expression of class I MHC antigens on murine epideımdl Langerhans cells $J$ Immunol 1994, 153 110-16

33 Ferrara JL Cytokine dysregulation as a mechanism of graft versus host disease Curr Opin Immunol 1993, 5 794-99 